\title{
Thyroid hormone and leptin in the testis
}

\author{
Cristiane Fonte Ramos ${ }^{1 *}$ and Ariane Zamoner ${ }^{2}$ \\ Laboratory of Morphometry, Metabolism and Cardiovascular Disease, Department of Anatomy, Biomedical Center, Institute of Biology, \\ State University of Rio de Janeiro, Rio de Janeiro, Brazil \\ ${ }^{2}$ Departamento de Bioquímica, Centro de Ciências Biológicas, Universidade Federal de Santa Catarina, Florianópolis, Brazil
}

\section{Edited by:}

Pei-San Tsai, University of Colorado, USA

\section{Reviewed by:}

Encarnación Capilla, University of Barcelona, Spain

T. John Wu, Uniformed Services University of the Health Sciences, USA

\section{*Correspondence}

Cristiane Fonte Ramos, Laboratório de Morfometria, Metabolismo e

Doença Cardiovascular, Centro

Biomédico, Instituto de Biologia,

Universidade do Estado do Rio de Janeiro. Av 28 de Setembro 87 fds,

Rio de Janeiro 20551-030, RJ, Brazil e-mail: cristiane@pesquisador. cnpq.br
Leptin is primarily expressed in white adipose tissue; however, it is expressed in the hypothalamus and reproductive tissues as well. Leptin acts by activating the leptin receptors (Ob-Rs). Additionally, the regulation of several neuroendocrine and reproductive functions, including the inhibition of glucocorticoids and enhancement of thyroxine and sex hormone concentrations in human beings and mice are leptin functions. It has been suggested that thyroid hormones (TH) could directly regulate leptin expression. Additionally, hypothyroidism compromises the intracellular integration of leptin signaling specifically in the arcuate nucleus. Two TH receptor isoforms are expressed in the testis, TRa and TRb, with TRa being the predominant one that is present in all stages of development. The effects of TH involve the proliferation and differentiation of Sertoli and Leydig cells during development, spermatogenesis, and steroidogenesis. In this context, TH disorders are associated with sexual dysfunction. An endocrine and/or direct paracrine effect of leptin on the gonads inhibits testosterone production in Leydig cells. Further studies are necessary to clarify the effects of both hormones in the testis during hypothyroidism. The goal of this review is to highlight the current knowledge regarding leptin and $\mathrm{TH}$ in the testis.

Keywords: leptin, thyroid hormones, male reproductive tissue, testis, adipose tissue

\section{INTRODUCTION}

The role of thyroid hormones (TH) and leptin in testicular physiology is not fully understood. Receptors for both hormones are present in the testis $(1,2)$, and some reproductive functions have been described as being a result of $\mathrm{TH}$ or leptin actions in the testis, although the interaction between these two hormones should be further investigated.

Leptin plays a key role in body weight homeostasis and has recently emerged as a relevant neuroendocrine mediator in different cell types, including testicular cells (3). This hormone appears to act by inhibiting testicular steroidogenesis, leading to reduced levels of testosterone and modulation of gene expression (Figure 1).

The involvement of $\mathrm{TH}$ in the modulation of male reproductive system development and function has been neglected for several years, because of the demonstration that the adult male gonad was metabolically unresponsive to these hormones in the 1950s (4). In addition, although hyper- and hypothyroidism have no apparent clinical relevance regarding signs and symptoms related to male gonadal function, compared with the systemic effects induced by these diseases, it has been demonstrated that thyroid dysfunction might affect biochemical, morphological, and physiological aspects of testicular development (4-8). In recent decades, several studies have reported important roles for $\mathrm{TH}$ in modulating testicular development $(2,9-11)$.

The TH effects involve the proliferation and differentiation of Sertoli and Leydig cells during development, spermatogenesis, and steroidogenesis, and its disorders are correlated with sexual dysfunction. An endocrine and/or direct paracrine effect of leptin on the gonads inhibits testosterone production in Leydig cells.
Although further studies are necessary to clarify the effects of these hormones in the testis during hypothyroidism, the goal of this review is to highlight the current knowledge regarding leptin and $\mathrm{TH}$ in the testis.

\section{LEPTIN \\ SYNTHESIS AND SECRETION}

Adipose tissue is recognized as an endocrine organ that secretes steroid hormones, including glucocorticoids, growth factors, enzymes, and pro- and anti-inflammatory adipocytokines $(12,13)$. Leptin is the prototype adipokine that was identified as the product of the $o b$ gene by its action in reducing appetite, increasing energy expenditure through action in the brain and then decreasing body weight and fat mass (14). Although anthropometric and clinical features (e.g., gender, fat mass/fat distribution, hormones, and cytokines) might influence the secretion pattern of leptin, the crucial factors that regulate serum leptin levels appear to be caloric intake and the amount of energy stored in adipocytes (15).

Leptin acts by activating leptin receptors (Ob-Rs). Several Ob$\mathrm{R}$ isoforms, resulting from alternative splicing, convey differing biological activities and are involved in mediating the actions of leptin in the brain and peripheral organs. The long isoform (Ob$\mathrm{Rb}$ ) is expressed abundantly in the hypothalamic arcuate nucleus $(\mathrm{ARH})$, ventromedial $(\mathrm{VMN})$, and dorsomedial nuclei (DMN), and is the predominant signaling form of the receptor (16). Ob- $\mathrm{Rb}$ has the longest cytoplasmatic domain, which contains the Janus Kinase (JAK) binding domain, box 1 and 2, and the consensus sequence for the signal transducers and activators of transcription (STAT) binding. Other forms have no (Ob-Re) or short (Ob-Ra, Ob-Rc-Ob-Rf) cytoplasmatic domains, which contain only box 1 


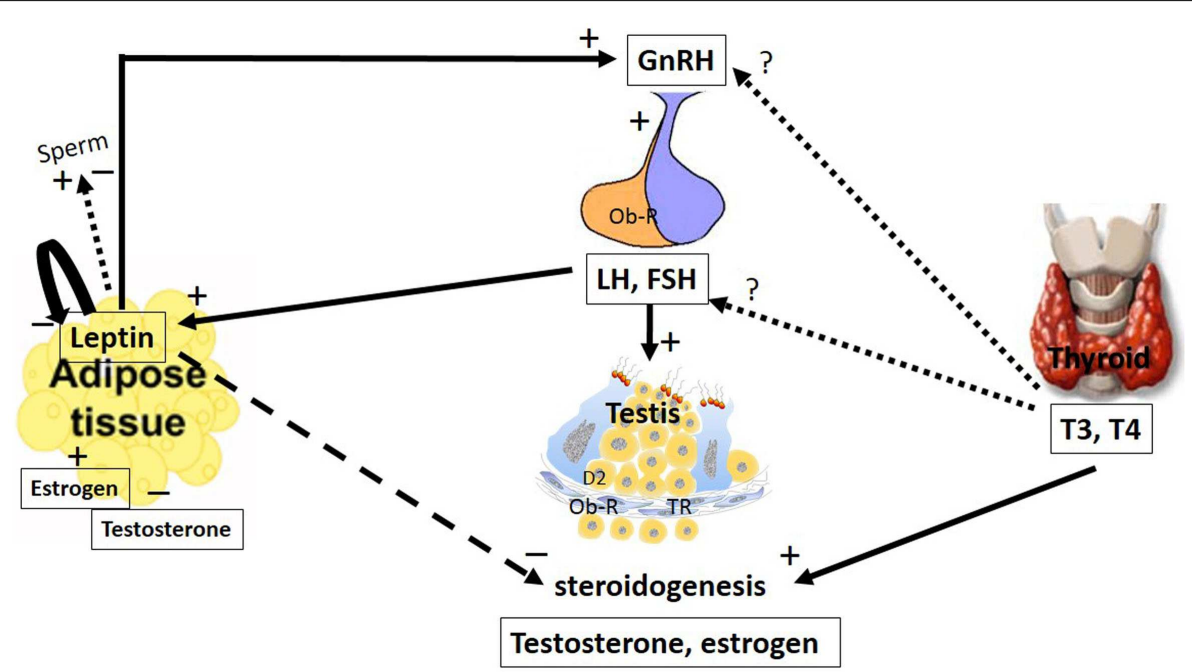

FIGURE 1 |The major pathways by which leptin and TH interact with the hypothalamic-pituitary axis to regulate testis function. The hypothalamic-pituitary-gonadal axis controls reproduction. $\mathrm{GnRH}$ is secreted from the hypothalamus by $\mathrm{GnRH}$ expressing neurons, stimulating the anterior portion of the pituitary gland to produce and secrete LH and FSH, whose function is to stimulate the gonads to produce estrogen and testosterone. Leptin plays a role in reproduction by stimulating $\mathrm{GnRH}$ secretion. Stimulatory and inhibitory effects of leptin on sperm were described. Additionally, leptin has an inhibitory effect on the gonads, inhibiting steroidogenesis and decreasing serum levels of testosterone and estradiol. These hormones could regulate leptin secretion in a feedback mechanism; however, estradiol stimulates and testosterone inhibits leptin secretion. $\mathrm{LH}$ and $\mathrm{FSH}$ are other hormones that stimulate leptin secretion. Leptin is capable of autoregulating its own secretion. The role of the thyroid hormones, $T_{4}$ and $T_{3}$, at the hypothalamic and pituitary levels remain controversial. However, in the testes, these hormones stimulate steroidogenesis. The arrays indicate solid (stimulatory), dashed (inhibitory), and dotted (uncertain) signals. $\mathrm{GnRH}$, gonadotropin-releasing hormone; LH, luteinizing hormone; FSH, follicle-stimulating hormone; $T_{3}, 3,5,3^{\prime}$-triiodo-L-thyronine; $T_{4}$, thyroxine; Ob-R, leptin receptors; TR, thyroid receptor.
(17). These short isoforms of the leptin receptor are distributed in almost all the peripheral tissues, including ovary $(18,19)$, prostate (20-22), and testis (23) tissues, suggesting the direct effects of leptin on these organs. In addition to JAK/STAT, other pathways are involved in leptin signaling, such as mitogen-activated protein kinase (MAPK), including extracellular factor-regulated kinases 1 and 2 [ERK1 and ERK (2)] and 5'-AMP-activated protein kinase (AMPK). Additionally, leptin presents cross talk with insulin-induced pathways by stimulating insulin receptor substrates (IRS) and then initiating phosphoinositide 3-kinase activity (PI3K) $(17,24,25)$. Leptin has been reported to induce suppressors of cytokine-signaling 3 (SOCS) expression, which are capable of inhibiting the JAK/STAT pathway via a feedback mechanism (26). During prolonged receptor stimulation by leptin, the inhibition of JAK phosphorylation is mediated by SOCS3, and leptin can act as a negative regulator of its own signaling.

Leptin secretion could be regulated by different mechanisms (Figure 2). In adipocyte tissue, leptin secretion could be stimulated by insulin, glucocorticoids, and cytokines (i.e., tumor necrosis factor a), whereas leptin release is inhibited by catecholamines, free fatty acids, cold exposure, and TH $(27,28)$. Estrogens induce leptin production, whereas androgens suppress it (Figure 1), thus explaining the sexual dimorphism in serum leptin levels $(29,30)$. A negative correlation between leptin and testosterone levels has been described in men and boys $(31,32)$. It has been demonstrated that leptin could control its own synthesis in adipose tissues by a negative feedback mechanism between the hormone and its receptor (Figure 1) (33). This autoregulatory mechanism was also shown in the prostate (34), however, there is no report of this mechanism in relation to the testis.

\section{LEPTIN AND THE HYPOTHALAMIC-PITUITARY-GONADAL AXIS}

Leptin inhibits appetite and weight gain by its action in the hypothalamus by activating proopiomelanocortin (POMC)/cocaineand amphetamine-related peptide (CART) while inhibiting the neuropeptide Y (NPY)/agouti-related protein (AgRP) neurons (35-38). In addition to this central action, leptin has been implicated in other roles, including reproductive ones where leptin stimulates gonadotropin-releasing hormone ( $\mathrm{GnRH})$ secretion (Figure 1). However, if leptin role is direct or not is still controverse. Some studies suggest a direct role of leptin based on the fact that the neurons secreting GnRH express Ob-R $(39,40)$. Watanobe (41) showed that leptin acts directly at the median eminence (ME), the anatomical structure where the axonal fibers of GnRH neurons are terminated before the neurohormone is released into the portal circulation (42); however, little or no co-expression of the leptin receptor is demonstrated at the medial preoptic area (MPOA) of the hypothalamus, which is the site where the majority of the GnRH neuronal cell bodies exist (42). This result, among others (43-45), suggests that leptin might influence GnRH secretion indirectly through interneurons and other pathways.

In the rat testis, leptin, at doses ranging from 2 to $500 \mathrm{ng} / \mathrm{mL}$, exerted dose-dependent inhibitory effects on human chorionic gonadotropin (hCG)-stimulated testosterone production (46). Therefore, in addition to having a stimulatory effect at the hypothalamic-pituitary level, leptin appears to have an inhibitory effect at the gonadal level.

\section{OTHER SITES THAT MEDIATE LEPTIN ACTION ON REPRODUCTION}

Gonadotropin-releasing hormone is also regulated by adiponectin, which is an adipocytokine produced by adipose tissue and 


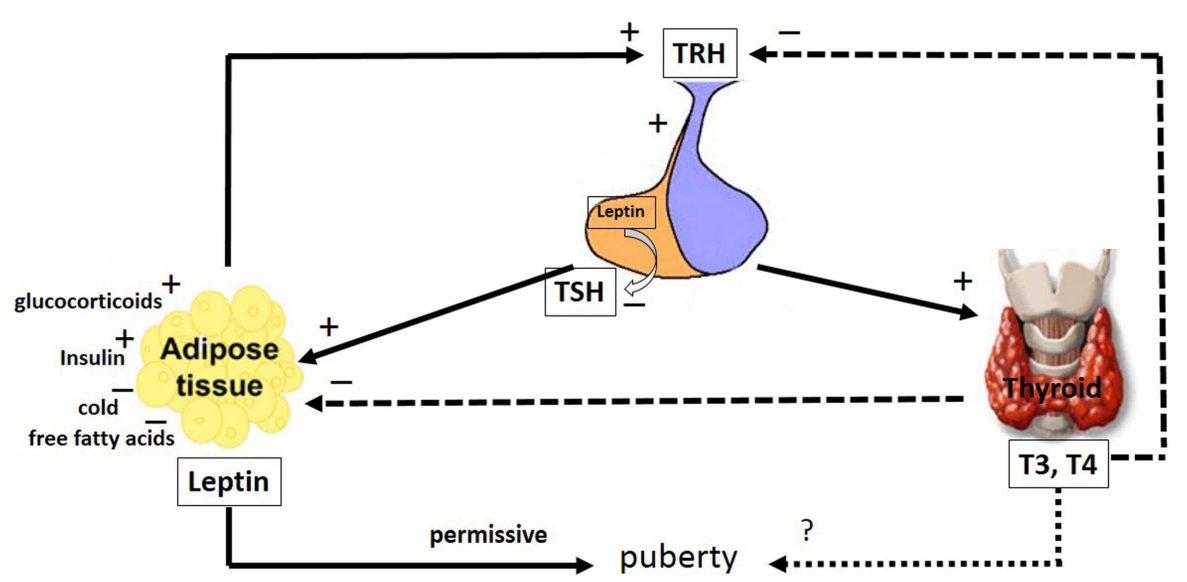

FIGURE 2 |The major pathways by which leptin interacts with the hypothalamic-pituitary-thyroid axis. The hypophysiotropic TRH neurons are metabolic integrators that are regulated by leptin and the thyroid hormones. TRH is secreted from the PVN of the hypothalamus and stimulates the anterior portion of the pituitary gland to produce and secrete TSH, whose function is to stimulate the thyroid gland to produce the thyroid hormones, $T_{4}$ and $T_{3}$. These hormones regulate the activity of $\mathrm{TRH}$ neurons in the hypothalamus by a classical negative feedback pathway. Leptin stimulates $\mathrm{TRH}$ secretion in the hypothalamus. Leptin produced in the pituitary is capable of inhibiting TSH secretion. Leptin secretion from adipose tissues is regulated by stimulatory factors such as $\mathrm{TSH}$, glucocorticoids, $\mathrm{T}_{4}$ and $\mathrm{T}_{3}$ and insulin as well as inhibitory factors such as, cold and free fatty acids. Leptin and the thyroid hormones, $T_{4}$ and $T_{3}$, have a role in puberty; however, whereas the leptin role is permissive, the $T_{4}$ and $T_{3}$ role remains uncertain. The arrays indicate: solid (stimulatory), dashed (inhibitory), dotted (uncertain) signals. $\mathrm{TRH}$, thyreotrophin release hormone; $\mathrm{TSH}$, pituitary tireotropin; $\mathrm{T}_{3}$, 3,5,3'-triiodo-L-thyronine; $\mathrm{T}_{4}$, thyroxine. See text for details. regulates metabolic function, as does leptin; the amount of GnRH in the circulation is inversely proportional to body fat (47). It has been demonstrated that adiponectin might provide a link between obesity and abnormal reproductive functioning by decreasing luteinizing hormone $(\mathrm{LH})$ secretion and inhibiting $\mathrm{GnRH}$ receptor (GnRHR) mRNA expression in the pituitary $(48,49)$. At the level of the hypothalamus, adiponectin reduces $\mathrm{GnRH}$ expression and secretion (50), whereas GnRH decreases adiponectin expression in the pituitary (51). Additionally, adiponectin appears to mediate basal and hCG-stimulated testosterone secretion by the testis $(52,53)$ in a rat model.

Ghrelin is another orexigenic factor that acts with NPY and AgRP to influence feeding and reproduction. Whereas leptin stimulates GnRH secretion, ghrelin exerts a negative effect on this hormone secretion and on GnRH-induced gonadotropin secretion; however, it appears that at basal conditions, ghrelin presents stimulatory actions on $\mathrm{LH}$ and follicle-stimulating hormone (FSH) secretion (54). Relative to NPY, both stimulatory and inhibitory effects on GnRH have been observed (55-57). AgRP is expressed in leptin responsive neurons of the ARH and the ablation of such neurons in leptin or Ob-R deficient mice restores fertility (58-60).

Among the anorexigenic factors that affect the reproductive system, the $\alpha$-melanocyte-stimulating hormone ( $\alpha$-MSH) from POMC neurons and CART from interneurons of the ARH mediate the leptin influence on GnRH secretion $(61,62)$. Additionally, nitric oxide (NO) released from adrenergic interneurons is capable of inducing GnRH release from GnRH neurons (23).

Another site that mediates leptin action on reproduction is the kisspeptin neurons in the ARH. Although a small amount of kisspeptin might be sufficient to trigger puberty (63), deletion of Ob-R from kisspeptin neurons (64) or ablation of more than $95 \%$ of kisspeptin neurons prior to puberty resulted in normal puberty and fertility (65). It appears that leptin signaling in these neurons arise only after completion of sexual maturation (66). Kisspeptin neurons connect to NPY and POMC neurons (67) are another link to the integration of leptin effects on nutrition and reproduction. Kisspeptin neurons have insulin receptors that could be interesting for their effect on reproduction. Deletion of the insulin receptor from kisspeptin neurons showed a puberty delay; however, fertility was normal (68), suggesting that insulin is the potential mediator of reproduction from kisspeptin neurons.

\section{EXPRESSION OF LEPTIN AND Ob-R IN TESTIS}

In 1997, the first demonstration of Ob-R expression in the murine testis was published. The authors showed the messenger RNA (mRNA) for the common extracellular domain of Ob-R in spermatic and Leydig cells by in situ hybridization (1). Later, several studies showed that it is ubiquitous among species. Ob-R specific immunostaining was observed in the testicular interstitium of rats at an embryonic age of 19.5 days and not at an embryonic age of 14.5 days, whereas in postnatal life, it was evident only after sexual maturation (35, 60, 90 days old) and was confined to Leydig cells. No immunoreaction was observed in the seminiferous tubules. Ob-R mRNA expression was present at all ages. Ob-Ra and Ob$\mathrm{Rb}$ mRNA presented a similar expression pattern, increasing from younger to older ages. The authors demonstrated that the Ob-R mRNA levels were higher in late versus early embryonic testes, as well as in adult versus immature rat testes (69). Other studies have shown a developmental Ob-R mRNA expression from 15- to 75-day old rats in constant relative levels; however, if only $\mathrm{Ob}-\mathrm{Rb}$ is considered, its expression was higher near puberty, at 30 days, declining after that period (70).

Leptin expression has been detected by immunohistochemistry techniques in mouse germ cells that are cell-type and stage specific 
and it was undetected in mouse Leydig cells. The authors suggest that leptin produced in testicular stem cells during the developmental stage might act on these cells in an autocrine manner to mediate their renewal (71). The developmental expression profiles of Ob-Ra, Ob-Rb, and Ob-Re show constant mRNA expression in 5-, 10-, 20-, 30-, and 60-day-old mice testis. However, in purified mouse Leydig cells, in which mRNA for leptin and Ob-Rb are not present in 14-and 60-day old mice, $\mathrm{Ob}-\mathrm{Ra}$ and $\mathrm{Ob}-\mathrm{Re}$ are expressed at both ages (71). Recently, mRNA for different Ob-R isoforms was detected in the adult rat testis (21).

Leptin caused STAT 3 phosphorylation after in vitro incubation of isolated seminiferous tubules, demonstrating that $\mathrm{Ob}-\mathrm{R}$ is functional and an activator of signal transduction mechanisms in germ cells (72). Corroborating this result, recently it was shown that leptin activates STAT3 signaling in the testis and that SOCS3 expression is regulated by leptin in this tissue (73).

\section{LEPTIN ACTIONS}

Considering that impaired reproductive function in the genetically obese (ob/ob) mouse was previously demonstrated $(74,75)$, leptin might be one of the hormones involved in the pathogenesis of infertility. Corroborating this hypothesis, the exogenous intraperitoneal administration of leptin in sterile ob/ob mice eliminated the sterility defect (76).

In the testis, it has been demonstrated that leptin might pass the blood-testis barrier by a passive, non-saturable process $(77,78)$. In this tissue, leptin acts as an inhibitory signal for testicular steroidogenesis (Figure 1), which might partially explain the link between decreased testosterone secretion and hyperleptinemia in obese men $(79,80)$. Decreased gene expression of some upstream factors in the steroidogenic pathway, such as steroidogenic factor-1 (SF1), steroidogenic acute regulatory protein (StAR), and cytochrome $\mathrm{P} 450$, has been demonstrated to be involved in the molecular mechanism responsible for leptin-induced inhibition of testosterone secretion (81). Moreover, the inhibitory effects of leptin on steroidogenesis have been observed in the adrenal gland and ovaries, which are steroidogenic tissues as well (82-84).

Besides testosterone synthesis, leptin can also regulate estrogen synthesis by regulating aromatase enzyme in other tissues of the reproductive system such as prostate and mammary gland (20, 34, $85,86)$. We were unable to find studies showing the effects of leptin upon aromatase in the testis.

Some other effects of leptin that can affect fertility have been already demonstrated. Leptin can alter the weight and volume of the testicles, the diameter of the seminiferous tubules, and the numbers of spermatogonia, spermatocytes, sperm, and Leydig cells (73). Also the fact that leptin is present in the human seminal plasma (87-89) and Ob-R is present at the tail region of ejaculated spermatozoa (89) as well as the relationship between leptin and sexual hormones suggests that leptin could directly or indirectly regulate sperm function.

\section{OBESITY AND TESTIS}

The effects of obesity on testis and male reproduction have been demonstrated in recent years (90). The decrease in testosterone levels as a consequence of the high leptin levels present in obese patients (91) might cause sexual dysfunction (92). However, the mechanisms involved in the association between obesity and a decrease in male fertility are complex and not completely understood on the basis of the current literature.

A high-fat diet leads to increased leptin levels, decreased plasma testosterone level, a decline in sperm motility, Leydig cell damage, and oxidative stress, as well as a decreased testis and epididymis relative coefficient in mice. The reproductive hormone imbalance observed in obesity might affect the antioxidant status in testes. The authors suggest that the excessive oxidative stress induced by obesity affects the normal histological structures and function of testicular tissue (93). In addition, the association of testicular oxidative stress and alterations in male reproduction and fertility has been demonstrated in other conditions such as thyroid dysfunctions (94-97).

Although consensus on the effects of obesity on fertility exists, particularly in relation to sperm count, concentration and motility, there is not a complete overall agreement (98). The lack of consensus is possibly because the majority of studies involve men presenting to fertility clinics, which could clearly bias toward subfertile men, and many might have other lifestyle related comorbidities affecting spermatogenesis. Different methodologies applied in various studies could contribute to the variability of the results. Some of the fertility alterations could occur because of the effects of leptin on other tissues of the reproductive systems that express Ob-R as well, such as the epididymis (99), prostate (20-22), and seminal vesicles (22).

Testosterone is a very important hormone for maintaining reproductive function and fertility. All the reproductive tissues and spermatogenesis are testosterone-dependent. Although androgen could regulate leptin synthesis and secretion in adipose tissues $(29,30)$ and leptin could regulate the expression of androgen receptors in others tissues, such as the prostate $(20,34)$, we were unable to find studies showing any interaction between leptin and testosterone or androgen receptors in the testis.

These findings clearly demonstrate that leptin functionally regulates the male gonadal axis by acting at different levels of the hypothalamic-pituitary-testicular system.

\section{THYROID HORMONE}

\section{THYROID HORMONE REGULATION}

As major regulators of serum $\mathrm{TH}$ levels, the hypophysiotropic thyreotrophin release hormone (TRH) neurons of the paraventricular nuclei (PVN) play important roles in the control of energy homeostasis (100). These neurons regulate $\mathrm{TH}$ production through the release of TRH at the ME, which stimulates pituitary tireotropin (TSH) release (Figure 2). TSH then stimulates the thyroid gland to produce $\mathrm{TH}$. These hormones regulate the activity of TRH neurons in the hypothalamus by a classical negative feedback pathway (Figure 2) (101-103). TRH neurons receive neuronal projections from POMC and NPY containing hypothalamic neurons (104-108), brainstem catecholaminergic neurons $(103,109,110)$, and neurochemically uncharacterized neurons in the DMN (111).

Thyroid hormones play critical roles in normal pre- and postnatal growth and development. These hormones are essential for the regulation of metabolism in nearly all mammalian tissues, including the testis $(112,113)$. 


\section{DEIODINATION}

Proper intracellular TH concentrations are required for most hormonal actions and for cellular metabolism. Thyroxine $\left(\mathrm{T}_{4}\right)$ is the major TH secreted from the thyroid gland; however, in target tissues other hormones could be produced. In peripheral tissues, there are important seleno enzymes known as deiodinases (D1,D2, and D3) that metabolize $\mathrm{TH}$, regulating local TH availability (114). D1 and D2 catalyze the removal of the iodine atom in the outer ring position, generating 3,5,3'-triiodo-L-thyronine $\left(\mathrm{T}_{3}\right)$. D3 catalyzes the removal of iodine from the inner ring position, generating an inactive hormone, as reverse $\mathrm{T}_{3}\left(3,3^{\prime}, 5^{\prime}\right.$-triiodothyronine or $\left.\mathrm{rT}_{3}\right)$.

These three deiodinases, D1, D2, and D3, are expressed in the testis at different levels, from weanling to adult life (115). D3 activity predominates in the developmental period and then declines in adult life. Although D1 and D2 are present in the testis, their relative levels of activity indicate that D2 is the predominant activating enzyme in the testis $(115,116)$.

Thyroid hormone transport across the plasma membrane is a crucial step in $\mathrm{TH}$ signaling. Several $\mathrm{TH}$ transporter families have been identified; however, only specific TH cell-membrane transporter (MCT) 8 and 10 and organic anion-transporting polypeptide 1c1 (Oatp1c1) have been shown to be specific $\mathrm{TH}$ transporters (117). Inside the cell, $\mathrm{T}_{3}$ binds to nuclear THs, which are ligand-regulated transcription factors that bind THs and DNA enhancer sequences in the promoter region of target genes and interact with co-repressor and co-activator complexes $(118,119)$.

\section{SIGNALING}

Thyroid hormone nuclear effects are mediated by TRa and TRb, which are members of the steroid/thyroid hormone receptor superfamily (120). The activation of these receptors modulates gene transcription and signal transduction to initiate intra-nuclear changes in cell metabolism $(121,122)$. Because the genomic actions of $\mathrm{TH}$ on gene regulation require many steps, $\mathrm{TH}$-induced changes in gene expression are generally long lasting $(113,120)$.

The TR are encoded by two different genes, TRa and TRb. Alternative splicing leads to the production of several peptide isoforms, five of which have been described: TRa1, TRa2, TRa3, TRb1, and TRb2. TRa2 and TRa3 lack a hormone-binding domain and are hypothesized to function as $\mathrm{TH}$ inhibitors by competing for binding at the thyroid response elements (TREs), resulting in the suppression of transcription (123-128). Within the seminiferous epithelium, the expression of TRs is developmentally regulated, and Sertoli cells express the TRa1 and TRa2 isoforms (85).

The active TRal isoform is expressed in human and rat testicular Sertoli cells, with maximal expression in late fetal and early neonatal life. TRb1 is found in interstitial and germ cells during neonatal development as well as in the adult testis, although at a much lower level (129-132). The fetal and prepubertal ages are periods of maximal expression of TRa1 and TRa2 in Sertoli cells, demonstrating a critical window for $\mathrm{TH}$ action in the testis, in rats (2) and in human beings (133). The immature stage of sexual development coincides with the maximal TRal activity in response to $\mathrm{T}_{3}(2)$. The TRa2 isoform does not bind to $\mathrm{T}_{3}$, and it has been suggested that TRa 2 most likely exerts a dominant negative effect on the actions of other TR isoforms (134). Considering the developmental regulation of TR expression in the Sertoli cells, it was shown that the ratio of TRa2/TRa1 increases progressively from the fetal period to adulthood. This increase reinforces the participation of TRal during the prepubertal period and, consequently, its involvement in testis differentiation and development (133). It could be proposed that TH play pivotal roles in testicular differentiation with maximal effects during the prepubertal period.

Although the classical mechanism of action for $\mathrm{TH}$ involves the modulation of gene transcription (genomic action), it has been frequently proposed that the membrane-initiated effects (non-genomic actions) of these hormones might be mediated by plasma membrane receptors. The effects triggered by cell-surface receptors are typically independent of protein synthesis (112). Although $\mathrm{T}_{3}, \mathrm{~T}_{4}$, and $\mathrm{rT}_{3}$ might trigger non-genomic effects, $\mathrm{T}_{4}$ and $\mathrm{rT}_{3}$ are more potent than $\mathrm{T}_{3}$ in testicular cells (135-138), reinforcing a role for these hormones as physiological signals controlling reproductive functions through cell surface-initiated mechanisms.

\section{THYROID HORMONE FUNCTION IN TESTIS}

$\mathrm{T}_{3}$ regulates the maturation and growth of the testis, controlling Sertoli and Leydig cell proliferation and differentiation during testicular development in rats and other mammalian species $(5,139)$. Possible mechanisms underlying the effects of TH on Sertoli cell proliferation have been recently proposed. The authors demonstrated that TH limits postnatal Sertoli cell proliferation by activation of the TRa1 present in these cells. They provided evidence that the regulation of the $\mathrm{Cdk} 4 / \mathrm{JunD} / \mathrm{c}-$ myc pathway might be involved in this negative control in mice (140). The testis size and sperm production are directly associated with the total Sertoli cell number during adulthood (141). The hormonal factors controlling the duration of Sertoli cell proliferation are critical determinants of male fertility (4). Although an adequate number of these cells is crucial for future male fertility, the factors controlling Sertoli cell survival, proliferation, and maturation require further investigation.

The effects of TH on Sertoli cells occurs through different and perhaps interconnected mechanisms (142) including the following: the expression of cell cycle regulators p27 and p21 (143); the inhibition of aromatase at the basal conditions and after FSH stimulus $(144,145)$ as well as the aromatase gene transcription (146); the increase in the levels of androgen-binding proteins (ABP) (129), which increases the availability of this steroid hormone $(147,148)$; the increase in the androgen receptor (AR) expression (129); the increase in the LH receptor (LHR) protein expression, although the mRNA is reduced (149); and the increase in the levels of the gap junction protein connexin 43 in the testis (150). For revision, see Tarulli et al. (142).

The Sertoli cells provide physical support to germ cells and are essential for the creation of an adequate and protected microenvironment for germ cell development. These cells are responsible for the secretion of $\mathrm{a} \mathrm{Cl}^{-}$and $\mathrm{K}^{+}$-rich fluid into the seminiferous tubule lumen $(151,152)$. The $\mathrm{Ca}^{2+}$-dependent $\mathrm{Cl}^{-}$secretion by Sertoli cells into the extracellular fluid is under the control of extracellular nucleotide levels (153); extracellular ATP has been shown to induce intracellular $\mathrm{Ca}^{2+}$ uptake in Sertoli cells (154). Our group previously demonstrated that $\mathrm{T}_{3}$ and $\mathrm{T}_{4}$ could inhibit NTPDase activity, with a consequent decrease in extracellular ATP 
hydrolysis; this reduction in hydrolysis leads to increased levels of ATP in the extracellular medium (10). It has been demonstrated that $\mathrm{TH}$ induces $\mathrm{Ca}^{2+}$-dependent signaling pathways in testicular cells $(11,112,136,155)$. It is possible to suggest that TH action might increase the extracellular ATP levels, leading to a $\mathrm{Ca}^{2+}$ influx and consequent chloride-rich fluid secretion by the Sertoli cells.

The expression of specific TRs in prepubertal Sertoli cells implies the existence of an early and critical influence of TH on testicular development and function (2). Although hypothyroidism leads to a marked delay in sexual maturation and development $(5,9,96)$, hyperthyroidism accelerates the appearance of the seminiferous tubule lumen (97), which marks the maturation of the Sertoli cells (156). Delayed testicular cell maturation provoked by neonatal hypothyroidism (96) is associated with reduced serum levels of the gonadotropins, FSH and LH (6).

Modifications in Sertoli cell maturation could be associated with alterations in androgen metabolism. The androgen/estrogen balance is crucial for testis development and male reproduction. The maximal expression and activity of aromatase is observed in Sertoli cells during the prepubertal period $(157,158)$, the period coincident with the maximal response of these cells to $\mathrm{TH}$ (4). Alterations in aromatase activity and expression, as well as in estrogen receptor levels, were demonstrated to be under TH control $(145,159,160)$. These estrogen-mediated events might affect androgen metabolism.

Thyroidectomy in adult rats led to decreased secretion of testosterone and $17 b$-hydroxy steroid dehydrogenase (HSD) activity (161). Leydig cells cultured from adult rats show an increase in testosterone and estrogen secretion after treatment with $\mathrm{T}_{3}$, under basal conditions and in response to LH (148). When Leydig cells are chronically stimulated with $\mathrm{T}_{3}$, there is an increase in the mRNA levels of the cytochrome P450 side-chain cleavage enzyme and a decrease in the cytochrome P450 17a-hydroxylase and $3 b$ HSD (162). An increase in the StAR mRNA and protein is observed after treatment of Leydig cells with $\mathrm{T}_{3}$, which contributes to steroid production $(162,163)$ (Figure 2).

Despite the important roles that THs play in the reproduction by acting in the testis, there is no consensus about how $\mathrm{TH}$ controls GnRH and gonandotropin synthesis and secretion. No pattern in the circulating gonadotropin hormones has been reported in hypothyroid conditions. These hormones could be unaltered, reduced, increased or $\mathrm{LH}$ reduced with unaltered FSH; and FSH could be increased with normal LH (147). In a recent study (149), the authors showed that rats submitted to hypothyroidism showed a reduction of the pituitary content of $\mathrm{LH}$, although they presented a high level of LH in serum. They attributed this divergent result to impaired LH renal clearance, because hypothyroidism could alter clearance (164) of adrenal drug excretion (165). There was a marked decrease of total testosterone serum concentration and a reduction in the amount of testicular LHR, although the LH mRNA receptor expression was shown to be increased. Exposure of testicular cells to a high concentration of $\mathrm{LH}$ reduces LHR mRNA and protein (166), which could explain the results observed by Romano et al. (149). Another possibility would be the reduction of the testosterone negative feedback regulating $\mathrm{LH}$ and FSH.

\section{INTERACTION BETWEEN LEPTIN AND THYROID HORMONES}

The hypophysiotropic TRH neurons are metabolic integrators, fixing the set point of the hypothalamic-pituitary-thyroid axis. Several studies have demonstrated that leptin modulates thyroid function, acting in the hypothalamus, pituitary and thyroid. Additionally, leptin modulates the activity of deiodinase enzymes (167-171). This hormone stimulates the hypothalamic production of TRH directly at the PVN $(106,172-174)$ and indirectly via the $\mathrm{ARH}$, which act as energy sensors. At the ARH, leptin upregulates the activity of the $\alpha$-MSH neurons and down-regulates the activity of the NPY/AgRP neurons. The $\alpha$-MSH neurons and NPY/AgRP neurons have stimulatory and inhibitory projections, respectively, to the TRH neurons (100, 106, 174-178).

Systemic administration of leptin increased the serum TSH concentration in rats, potentially because of the leptin action at the hypothalamus (Figure 2). Because the direct pituitary effect of leptin on TSH release was inhibitory, this TSH release might result from an autocrine-paracrine effect exerted by locally produced leptin (Figure 2) $(170,171)$. TSH significantly stimulated the leptin secretion by human adipose tissue in vitro, suggesting a new mechanism in the inter-relationship between adipose tissue and the thyroid axis (Figure 2) (179). It has been demonstrated that food deprivation, associated with low leptin levels, leads to decreased TSH synthesis in the pituitary and TRH in the hypothalamus $(171,180)$. The mechanisms underlying the secretion of tropic hormones from pituitary cells might involve the modulation of NO levels. Coiro and colleagues suggested that TRH stimulates TSH release via NO in humans (181). Corroborating these findings, Radwanska and Kosior-Korzecka (182) recently demonstrated that leptin-stimulated TSH secretion is dependent on NO release from the anterior pituitary cells of ewe lambs. In this context, the effect of leptin on the thyroid axis might modulate the effects of THs on the male reproductive system.

It has been proposed that leptin might be a trigger for the onset of puberty in children, because leptin levels increase in both girls and boys prior to pubertal gonadal activation (183). In girls, however, leptin concentrations continue to rise, likely due to stimulatory the effects of estrogen, while leptin concentrations decrease in boys, due to the inhibitory effects of testosterone $(29,30,183$, 184). However, data of Mann and colleagues (185) do not support the concept that a transient rise in leptin triggers the onset of puberty. They demonstrated that circulating leptin levels decline throughout puberty, and there is no transient rise of leptin prior or in association with the onset of puberty in male monkeys. Leptin, however, is currently thought to have a more permissive role in pubertal maturation, as the administration of exogenous leptin alone could not trigger early puberty in patients with congenital leptin deficiency (186). Although leptin probably is not the primary factor for puberty initiation, lower levels of this hormone could be associated with a delay in the onset of puberty (187). It has been shown that some developmental changes in the $\mathrm{T}_{4}$ levels parallel those of leptin. Whether the peripubertal changes observed in $\mathrm{T}_{4}$ levels suggest thyroid involvement in initiating pubertal events remains to be elucidated.

The relationship between $\mathrm{TH}$ and leptin serum levels is not completely understood; however, it has been demonstrated that leptin levels might be increased in the hyperthyroid state in 
humans (188). In addition, Asami and coworkers (189) have demonstrated a relationship between the serum levels of leptin and $\mathrm{TH}$ in children. A direct effect of leptin stimulating hepatic $\mathrm{TH}$ activation by modulation of deiodinase activity and expression was shown in chicken embryo hepatocytes (190). The authors demonstrated that the expression and activity of D1 were increased, whereas those of D3 were decreased, in leptin-treated cells. A D1increased gene expression and activity in the adipose tissues of obese humans was doccumented, suggesting a role for $\mathrm{T}_{3}$, formed from $\mathrm{T}_{4}$ by $\mathrm{D} 1$ activation in response to leptin, in the modulation of adipose tissue metabolism (191). These studies support that $\mathrm{TH}$ and leptin might act in conjuction in the modulation of several cell functions.

Corroborating the relationship between TH and leptin, it has been shown that hypothyroidism reduces the expression of members of the Ob-Rb-STAT3 signaling pathway in the basomedial hypothalamus and pituitary of rats; in addition, hypothyroid rats are resistant to the acute anorectic action of leptin (192). Additionally, hypothyroid mice exhibited decreased circulating leptin levels because of a decrease in the fat mass and reduced leptin expression in white adipose tissue. In neurons of the ARH, hypothyroid mice showed increased leptin receptor Ob-R expression and decreased suppression of the cytokine-signaling 3 transcript levels (193).

The main pathways by which leptin and TH interact with the hypothalamic-pituitary axis to regulate testis function are summarized in Figures $\mathbf{1}$ and 2 . This review is a first demonstration proposing explanations for the possible relationship between $\mathrm{TH}$ and leptin activity in the testis. Further studies are needed to clarify how these two important hormones might act together in modulating male reproduction.

\section{ACKNOWLEDGMENTS}

We acknowledge FAPESC, CNPq-Brazil, and CAPES for their grants and research scholarships. Funding: The research conducted in our laboratories is supported by grants from the Conselho Nacional de Desenvolvimento Científico e Tecnológico (CNPq-Brazil)/Edital Universal 14/2011/research grant \#479483/2011-6; Fundação de Apoio à Pesquisa Científica e Tecnológica do Estado de Santa Catarina (FAPESC) research grant "chamada pública FAPESC 04/2011 - Apoio a infra-estrutura de CT\&I para jovens pesquisadores” \#11,338/2012-7; Coordenação de Aperfeiçoamento de Pessoal de Nível Superior (CAPES-Brazil).

\section{REFERENCES}

1. Hoggard N, Mercer JG, Rayner DV, Moar K, Trayhurn P, Williams LM. Localization of leptin receptor mRNA splice variants in murine peripheral tissues by RT-PCR and in situ hybridization. Biochem Biophys Res Commun (1997) 232(2):383-7. doi:10.1006/bbrc.1997.6245

2. Jannini EA, Carosa E, Rucci N, Screponi E, D’Armiento M. Ontogeny and regulation of variant thyroid hormone receptor isoforms in developing rat testis. J Endocrinol Invest (1999) 22(11):843-8. doi:10.1007/BF03343656

3. Tena-Sempere M, Barreiro ML. Leptin in male reproduction: the testis paradigm. Mol Cell Endocrinol (2002) 188(1-2):9-13. doi:10.1016/S0303-7207(02) 00008-4

4. Jannini EA, Ulisse S, D'Armiento M. Thyroid hormone and male gonadal function. Endocr Rev (1995) 16(4):443-59. doi:10.1210/er.16.4.443

5. Holsberger DR, Cooke PS. Understanding the role of thyroid hormone in Sertoli cell development: a mechanistic hypothesis. Cell Tissue Res (2005) 322(1):133-40. doi:10.1007/s00441-005-1082-z
6. Palmero S, de Marchis M, Gallo G, Fugassa E. Thyroid hormone affects the development of Sertoli cell function in the rat. J Endocrinol (1989) 123(1):105-11. doi:10.1677/joe.0.1230105

7. Zamoner A, Barreto KP, Filho DW, Sell F, Woehl VM, Guma FC, et al. Propylthiouracil-induced congenital hypothyroidism upregulates vimentin phosphorylation and depletes antioxidant defenses in immature rat testis. $J$ Mol Endocrinol (2008) 40(3):125-35. doi:10.1677/JME-07-0089

8. Zamoner A, Barreto KP, Filho DW, Sell F, Woehl VM, Guma FC, et al. Hyperthyroidism in the developing rat testis is associated with oxidative stress and hyperphosphorylated vimentin accumulation. Mol Cell Endocrinol (2007) 267(12):116-26. doi:10.1016/j.mce.2007.01.005

9. Holsberger DR, Kiesewetter SE, Cooke PS. Regulation of neonatal Sertoli cell development by thyroid hormone receptor alpha1. Biol Reprod (2005) 73(3):396-403. doi:10.1095/biolreprod.105.041426

10. Zamoner A, Bruno AN, Casali EA, Corbelini PF, Diniz GP, Barreto-Chaves ML, et al. Genomic-independent action of thyroid hormones on NTPDase activities in Sertoli cell cultures from congenital hypothyroid rats. Life Sci (2006) 80(1):51-8. doi:10.1016/j.lfs.2006.08.020

11. Zamoner A, Corbelini PF, Funchal C, Menegaz D, Silva FR, Pessoa-Pureur R. Involvement of calcium-dependent mechanisms in T3-induced phosphorylation of vimentin of immature rat testis. Life Sci (2005) 77(26):3321-35. doi:10.1016/j.lfs.2005.05.042

12. Laclaustra M, Corella D, Ordovas JM. Metabolic syndrome pathophysiology: the role of adipose tissue. Nutr Metab Cardiovasc Dis (2007) 17(2):125-39. doi:10.1016/j.numecd.2006.10.005

13. Matsuzawa Y. The metabolic syndrome and adipocytokines. FEBS Lett (2006) 580(12):2917-21. doi:10.1016/j.febslet.2006.04.028

14. Halaas JL, Gajiwala KS, Maffei M, Cohen SL, Chait BT, Rabinowitz D, et al. Weight-reducing effects of the plasma protein encoded by the obese gene. Science (1995) 269(5223):543-6. doi:10.1126/science.7624777

15. Kelesidis T, Mantzoros CS. The emerging role of leptin in humans. Pediat Endocrinol Rev. (2006) 3(3):239-48.

16. Héritier A, Charnay Y, Aubert ML. Regional distribution of mRNA encoding the long form of leptin receptor in the mouse brain. Neurosci Res Commun (1997) 21(2):113-8. doi:10.1002/(SICI) 1520-6769(199709/10)21:2<113: :AID-NRC214>3.3.CO;2-X

17. Hegyi K, Fulop K, Kovacs K, Toth S, Falus A. Leptin-induced signal transduction pathways. Cell Biol Int (2004) 28(3):159-69. doi:10.1016/j.cellbi.2003.12.003

18. da Silveira Cavalcante F, Gombar FM, Ferreira RV, da Silva Faria T, Costa WS, Sampaio FJ, et al. Maternal protein-energy and energy-restricted diets during lactation possibly could program folliculogenesis and the ovarian expression of leptin and its different isoform receptors in rats. Fertil Steril (2009) 92(5):1755-7. doi:10.1016/j.fertnstert.2009.05.037

19. Ryan NK, Van der Hoek KH, Robertson SA, Norman RJ. Leptin and leptin receptor expression in the rat ovary. Endocrinology (2003) 144(11):5006-13. doi:10.1210/en.2003-0584

20. Alves-Pereira JL, Colli S, Marques DS, Sampaio FJ, Ramos CF. Molecular and morphometric analysis of the rat ventral prostate injected with leptin. Regul Pept (2012) 176(1-3):6-12. doi:10.1016/j.regpep.2012.02.002

21. Gombar FM, Ramos CF. Perinatal malnutrition programs gene expression of leptin receptors isoforms in testis and prostate of adult rats. Regul Pept (2013) 184:115-20. doi:10.1016/j.regpep.2013.03.009

22. Malendowicz W, Rucinski M, Macchi C, Spinazzi R, Ziolkowska A, Nussdorfer $\mathrm{GG}$, et al. Leptin and leptin receptors in the prostate and seminal vesicles of the adult rat. Int J Mol Med (2006) 18(4):615-8. doi:10.3892/ijmm.18.4.615

23. Yu WH, Walczewska A, Karanth S, McCann SM. Nitric oxide mediates leptininduced luteinizing hormone-releasing hormone (LHRH) and LHRH and leptin-induced LH release from the pituitary gland. Endocrinology (1997) 138(11):5055-8. doi:10.1210/endo.138.11.5649

24. Lin HY, Yang SH, Tang HY, Cheng GY, Davis PJ, Grasso P. Biologically active leptin-related synthetic peptides activate STAT3 via phosphorylation of ERK1/2 and PI-3K. Peptides (2014) 57:95-100. doi:10.1016/j.peptides.2014.04.007

25. Elias CF, Purohit D. Leptin signaling and circuits in puberty and fertility. Cell Mol Life Sci (2013) 70(5):841-62. doi:10.1007/s00018-012-1095-1

26. Sahu A. Leptin signaling in the hypothalamus: emphasis on energy homeostasis and leptin resistance. Front Neuroendocrinol (2003) 24(4):225-53. doi:10.1016/j.yfrne.2003.10.001

27. Ahima RS. Adipose tissue as an endocrine organ. Obesity (2006) 14(Suppl 5):242S-9S. doi:10.1038/oby.2006.317 
28. Considine RV. Regulation of leptin production. Rev Endocr Metab Disord (2001) 2(4):357-63. doi:10.1023/A:1011896331159

29. Machinal F, Dieudonne MN, Leneveu MC, Pecquery R, Giudicelli Y. In vivo and in vitro ob gene expression and leptin secretion in rat adipocytes: evidence for a regional specific regulation by sex steroid hormones. Endocrinology (1999) 140(4):1567-74. doi:10.1210/endo.140.4.6617

30. Machinal-Quelin F, Dieudonne MN, Pecquery R, Leneveu MC, Giudicelli Y. Direct in vitro effects of androgens and estrogens on ob gene expression and leptin secretion in human adipose tissue. Endocrine (2002) 18(2):179-84. doi:10.1385/ENDO:18:2:179

31. Wabitsch M, Blum WF, Muche R, Braun M, Hube F, Rascher W, et al. Contribution of androgens to the gender difference in leptin production in obese children and adolescents. J Clin Invest (1997) 100(4):808-13. doi:10.1172/ JCI119595

32. Luukkaa V, Pesonen U, Huhtaniemi I, Lehtonen A, Tilvis R, Tuomilehto J, et al. Inverse correlation between serum testosterone and leptin in men. J Clin Endocrinol Metabol. (1998) 83(9):3243-6. doi:10.1210/jcem.83.9.5134

33. Zhang Y, Olbort M, Schwarzer K, Nuesslein-Hildesheim B, Nicolson M, Murphy E, et al. The leptin receptor mediates apparent autocrine regulation of leptin gene expression. Biochem Biophys Res Commun (1997) 240(2):492-5. doi:10.1006/bbrc.1997.7622

34. Colli S, Silveira Cavalcante F, Peixoto Martins M, Sampaio FJ, da Fonte Ramos C. Leptin role in the rat prostate ventral lobe. Fertil Steril (2011) 95(4):1490e-3e. doi:10.1016/j.fertnstert.2010.12.029

35. Schwartz MW, Seeley RJ, Campfield LA, Burn P, Baskin DG. Identification of targets of leptin action in rat hypothalamus. J Clin Invest (1996) 98(5):1101-6. doi:10.1172/JCI118891

36. Korner J, Savontaus E, Chua SC Jr., Leibel RL, Wardlaw SL. Leptin regulation of Agrp and Npy mRNA in the rat hypothalamus. J Neuroendocrinol (2001) 13(11):959-66. doi:10.1046/j.1365-2826.2001.00716.x

37. Swart I, Jahng JW, Overton JM, Houpt TA. Hypothalamic NPY, AGRP, and POMC mRNA responses to leptin and refeeding in mice. Am J Physiol Regul Integr Comp Physiol (2002) 283(5):R1020-6. doi:10.1152/ajpregu.00501.2001

38. Munzberg H, Huo L, Nillni EA, Hollenberg AN, Bjorbaek C. Role of signal transducer and activator of transcription 3 in regulation of hypothalamic proopiomelanocortin gene expression by leptin. Endocrinology (2003) 144(5):2121-31. doi:10.1210/en.2002-221037

39. Magni P, Vettor R, Pagano C, Calcagno A, Beretta E, Messi E, et al. Expression of a leptin receptor in immortalized gonadotropin-releasing hormone-secreting neurons. Endocrinology (1999) 140(4):1581-5. doi:10.1210/endo.140.4.6622

40. Lebrethon MC, Vandersmissen E, Gerard A, Parent AS, Junien JL, Bourguignon JP. In vitro stimulation of the prepubertal rat gonadotropin-releasing hormone pulse generator by leptin and neuropeptide $\mathrm{Y}$ through distinct mechanisms. Endocrinology (2000) 141(4):1464-9. doi:10.1210/endo.141.4.7432

41. Watanobe H. Leptin directly acts within the hypothalamus to stimulate gonadotropin-releasing hormone secretion in vivo in rats. J Physiol (2002) 545(Pt 1):255-68. doi:10.1113/jphysiol.2002.023895

42. Lantos TA, Gorcs TJ, Palkovits M. Immunohistochemical mapping of neuropeptides in the premamillary region of the hypothalamus in rats. Brain Res Brain Res Rev (1995) 20(2):209-49. doi:10.1016/0165-0173(94)00013-F

43. Cunningham MJ, Clifton DK, Steiner RA. Leptin's actions on the reproductive axis: perspectives and mechanisms. Biol Reprod (1999) 60(2):216-22. doi:10.1095/biolreprod60.2.216

44. Quennell JH, Mulligan AC, Tups A, Liu X, Phipps SJ, Kemp CJ, et al. Leptin indirectly regulates gonadotropin-releasing hormone neuronal function. Endocrinology (2009) 150(6):2805-12. doi:10.1210/en.2008-1693

45. Louis GW, Greenwald-Yarnell M, Phillips R, Coolen LM, Lehman MN, Myers MG Jr. Molecular mapping of the neural pathways linking leptin to the neuroendocrine reproductive axis. Endocrinology (2011) 152(6):2302-10. doi:10.1210/en.2011-0096

46. Caprio M, Isidori AM, Carta AR, Moretti C, Dufau ML, Fabbri A. Expression of functional leptin receptors in rodent Leydig cells. Endocrinology (1999) 140(11):4939-47. doi:10.1210/en.140.11.4939

47. Hu E, Liang P, Spiegelman BM. AdipoQ is a novel adipose-specific gene dysregulated in obesity. J Biol Chem (1996) 271(18):10697-703. doi:10.1074/jbc. 271.18.10697

48. Lu M, Tang Q, Olefsky JM, Mellon PL, Webster NJ. Adiponectin activates adenosine monophosphate-activated protein kinase and decreases luteinizing hormone secretion in LbetaT2 gonadotropes. Mol Endocrinol (2008) 22(3):760-71. doi:10.1210/me.2007-0330

49. Rodriguez-Pacheco F, Martinez-Fuentes AJ, Tovar S, Pinilla L, Tena-Sempere M, Dieguez C, et al. Regulation of pituitary cell function by adiponectin. Endocrinology (2007) 148(1):401-10. doi:10.1210/en.2006-1019

50. Cheng XB, Wen JP, Yang J, Yang Y, Ning G, Li XY. GnRH secretion is inhibited by adiponectin through activation of AMP-activated protein kinase and extracellular signal-regulated kinase. Endocrine (2011) 39(1):6-12. doi:10.1007/ s12020-010-9375-8

51. Kim J, Zheng W, Grafer C, Mann ML, Halvorson LM. GnRH decreases adiponectin expression in pituitary gonadotropes via the calcium and PKA pathways. Reprod Sci (2013) 20(8):937-45. doi:10.1177/ 1933719112468947

52. Caminos JE, Nogueiras R, Gaytan F, Pineda R, Gonzalez CR, Barreiro ML, et al. Novel expression and direct effects of adiponectin in the rat testis. Endocrinology (2008) 149(7):3390-402. doi:10.1210/en.2007-1582

53. Chabrolle C, Tosca L, Rame C, Lecomte P, Royere D, Dupont J. Adiponectin increases insulin-like growth factor I-induced progesterone and estradiol secretion in human granulosa cells. Fertil Steril (2009) 92(6):1988-96. doi:10.1016/ j.fertnstert.2008.09.008

54. Fernandez-Fernandez R, Tena-Sempere M, Navarro VM, Barreiro ML, Castellano JM, Aguilar E, et al. Effects of ghrelin upon gonadotropinreleasing hormone and gonadotropin secretion in adult female rats: in vivo and in vitro studies. Neuroendocrinology (2005) 82(5-6):245-55. doi:10.1159/ 000092753

55. Khorram O, Pau KY, Spies HG. Release of hypothalamic neuropeptide Y and effects of exogenous NPY on the release of hypothalamic GnRH and pituitary gonadotropins in intact and ovariectomized does in vitro. Peptides (1988) 9(2):411-7. doi:10.1016/0196-9781(88)90277-X

56. Sutton SW, Toyama TT, Otto S, Plotsky PM. Evidence that neuropeptide Y (NPY) released into the hypophysial-portal circulation participates in priming gonadotropes to the effects of gonadotropin releasing hormone $(\mathrm{GnRH})$ Endocrinology (1988) 123(2):1208-10. doi:10.1210/endo-123-2-1208

57. Roa J, Herbison AE. Direct regulation of GnRH neuron excitability by arcuate nucleus POMC and NPY neuron neuropeptides in female mice. Endocrinology (2012) 153(11):5587-99. doi:10.1210/en.2012-1470

58. Israel DD, Sheffer-Babila S, de Luca C, Jo YH, Liu SM, Xia Q, et al. Effects of leptin and melanocortin signaling interactions on pubertal development and reproduction. Endocrinology (2012) 153(5):2408-19. doi:10.1210/en.20111822

59. Sheffer-Babila S, Sun Y, Israel DD, Liu SM, Neal-Perry G, Chua SC Jr. Agoutirelated peptide plays a critical role in leptin's effects on female puberty and reproduction. Am J Physiol Endocrinol Metabol. (2013) 305(12):E1512-20. doi:10.1152/ajpendo.00241.2013

60. Wu Q, Whiddon BB, Palmiter RD. Ablation of neurons expressing agoutirelated protein, but not melanin concentrating hormone, in leptin-deficient mice restores metabolic functions and fertility. Proc Natl Acad Sci U S A (2012) 109(8):3155-60. doi:10.1073/pnas.1120501109

61. Lebrethon MC, Vandersmissen E, Gerard A, Parent AS, Bourguignon JP. Cocaine and amphetamine-regulated-transcript peptide mediation of leptin stimulatory effect on the rat gonadotropin-releasing hormone pulse generator in vitro. J Neuroendocrinol (2000) 12(5):383-5. doi:10.1046/j.1365-2826.2000. 00497.x

62. Parent AS, Lebrethon MC, Gerard A, Vandersmissen E, Bourguignon JP. Leptin effects on pulsatile gonadotropin releasing hormone secretion from the adult rat hypothalamus and interaction with cocaine and amphetamine regulated transcript peptide and neuropeptide Y. Regul Pept (2000) 92(1-3):17-24. doi:10.1016/S0167-0115(00)00144-0

63. Popa SM, Moriyama RM, Caligioni CS, Yang JJ, Cho CM, Concepcion TL, et al. Redundancy in Kiss 1 expression safeguards reproduction in the mouse. Endocrinology (2013) 154(8):2784-94. doi:10.1210/en.2013-1222

64. Donato J Jr., Cravo RM, Frazao R, Gautron L, Scott MM, Lachey J, et al. Leptin's effect on puberty in mice is relayed by the ventral premammillary nucleus and does not require signaling in Kiss1 neurons. J Clin Invest (2011) 121(1):355-68. doi:10.1172/JCI45106

65. Mayer C, Boehm U. Female reproductive maturation in the absence of kisspeptin/GPR54 signaling. Nat Neurosci (2011) 14(6):704-10. doi:10.1038/ nn. 2818 
66. Cravo RM, Frazao R, Perello M, Osborne-Lawrence S, Williams KW, Zigman JM, et al. Leptin signaling in Kiss1 neurons arises after pubertal development. PLoS One (2013) 8(3):e58698. doi:10.1371/journal.pone.0058698

67. Backholer K, Smith JT, Rao A, Pereira A, Iqbal J, Ogawa S, et al. Kisspeptin cells in the ewe brain respond to leptin and communicate with neuropeptide Y and proopiomelanocortin cells. Endocrinology (2010) 151(5):2233-43. doi:10.1210/en.2009-1190

68. Qiu X, Dowling AR, Marino JS, Faulkner LD, Bryant B, Bruning JC, et al. Delayed puberty but normal fertility in mice with selective deletion of insulin receptors from Kiss 1 cells. Endocrinology (2013) 154(3):1337-48. doi:10.1210/ en.2012-2056

69. Caprio M, Fabbrini E, Ricci G, Basciani S, Gnessi L, Arizzi M, et al. Ontogenesis of leptin receptor in rat Leydig cells. Biol Reprod (2003) 68(4):1199-207. doi:10.1095/biolreprod.102.007831

70. Tena-Sempere M, Pinilla L, Zhang FP, Gonzalez LC, Huhtaniemi I, Casanueva FF, et al. Developmental and hormonal regulation of leptin receptor (ObR) messenger ribonucleic acid expression in rat testis. Biol Reprod (2001) 64(2):634-43. doi:10.1095/biolreprod64.2.634

71. Herrid M, O’Shea T, McFarlane JR. Ontogeny of leptin and its receptor expression in mouse testis during the postnatal period. Mol Reprod Dev (2008) 75(5):874-80. doi:10.1002/mrd.20796

72. El-Hefnawy T, Ioffe S, Dym M. Expression of the leptin receptor during germ cell development in the mouse testis. Endocrinology (2000) 141(7):2624-30. doi:10.1210/endo.141.7.7542

73. Yuan M, Huang G, Li J, Zhang J, Li F, Li K, et al. Hyperleptinemia directly affects testicular maturation at different sexual stages in mice, and suppressor of cytokine signaling 3 is involved in this process. Reprod Biol Endocrinol (2014) 12:15. doi:10.1186/1477-7827-12-15

74. Jones N, Harrison GA. Genetically determined obesity and sterility in the mouse. Proc Soc Study Fertil (1957) 9:51-64.

75. Swerdloff RS, Batt RA, Bray GA. Reproductive hormonal function in the genetically obese (ob/ob) mouse. Endocrinology (1976) 98(6):1359-64. doi:10.1210/ endo-98-6-1359

76. Barash IA, Cheung CC, Weigle DS, Ren H, Kabigting EB, Kuijper JL, et al. Leptin is a metabolic signal to the reproductive system. Endocrinology (1996) 137(7):3144-7. doi:10.1210/endo.137.7.8770941

77. Banks WA, McLay RN, Kastin AJ, Sarmiento U, Scully S. Passage of leptin across the blood-testis barrier. Am J Physiol (1999) 276(6 Pt 1):E1099-104.

78. von Sobbe HU, Koebnick C, Jenne L, Kiesewetter F. Leptin concentrations in semen are correlated with serum leptin and elevated in hypergonadotrophic hypogonadism. Andrologia (2003) 35(4):233-7. doi:10.1046/j.1439-0272.2003. 00565.x

79. Fui MN, Dupuis P, Grossmann M. Lowered testosterone in male obesity: mechanisms, morbidity and management. Asian J Androl (2014) 16(2):223-31. doi:10.4103/1008-682X.122365

80. Isidori AM, Caprio M, Strollo F, Moretti C, Frajese G, Isidori A, et al. Leptin and androgens in male obesity: evidence for leptin contribution to reduced androgen levels. J Clin Endocrinol Metab (1999) 84(10):3673-80. doi:10.1210/jcem.84.10.6082

81. Tena-Sempere M, Manna PR, Zhang FP, Pinilla L, González LC, Diéguez C, et al. Molecular mechanisms of leptin action in adult rat testis: potential targets for leptin-induced inhibition of steroidogenesis and pattern of leptin receptor messenger ribonucleic acid expression. J Endocrinol (2001) 170(2):413-23. doi:10.1677/joe.0.1700413

82. Kruse M, Bornstein SR, Uhlmann K, Paeth G, Scherbaum WA. Leptin downregulates the steroid producing system in the adrenal. Endocr Res (1998) 24(34):587-90. doi:10.3109/07435809809032650

83. Cherradi N, Capponi AM, Gaillard RC, Pralong FP. Decreased expression of steroidogenic acute regulatory protein: a novel mechanism participating in the leptin-induced inhibition of glucocorticoid biosynthesis. Endocrinology (2001) 142(8):3302-8. doi:10.1210/endo.142.8.8341

84. Serke H, Nowicki M, Kosacka J, Schroder T, Kloting N, Bluher M, et al. Leptindeficient $(\mathrm{ob} / \mathrm{ob})$ mouse ovaries show fatty degeneration, enhanced apoptosis and decreased expression of steroidogenic acute regulatory enzyme. Int J Obes (2012) 36(8):1047-53. doi:10.1038/ijo.2011.220

85. Subbaramaiah K, Howe LR, Bhardwaj P, Du B, Gravaghi C, Yantiss RK, et al. Obesity is associated with inflammation and elevated aromatase expression in the mouse mammary gland. Cancer Prev Res (2011) 4(3):329-46. doi:10.1158/1940-6207.CAPR-10-0381
86. Liu E, Samad F, Mueller BM. Local adipocytes enable estrogen-dependent breast cancer growth: role of leptin and aromatase. Adipocyte. (2013) 2(3):165-9. doi:10.4161/adip.23645

87. Camina JP, Lage M, Menendez C, Grana M, Garcia-Devesa J, Dieguez C, et al. Evidence of free leptin in human seminal plasma. Endocrine (2002) 17(3):169-74. doi:10.1385/ENDO:17:3:169

88. Glander HJ, Lammert A, Paasch U, Glasow A, Kratzsch J. Leptin exists in tubuli seminiferi and in seminal plasma. Andrologia (2002) 34(4):227-33. doi:10.1046/j.1439-0272.2002.00501.x

89. Jope T, Lammert A, Kratzsch J, Paasch U, Glander HJ. Leptin and leptin receptor in human seminal plasma and in human spermatozoa. Int J Androl (2003) 26(6):335-41. doi:10.1111/j.1365-2605.2003.00434.x

90. Dandona P, Dhindsa S. Update: hypogonadotropic hypogonadism in type 2 diabetes and obesity. J Clin Endocrinol Metab (2011) 96(9):2643-51. doi:10. 1210/jc.2010-2724

91. Hofstra J, Loves S, van Wageningen B, Ruinemans-Koerts J, Jansen I, de Boer $\mathrm{H}$. High prevalence of hypogonadotropic hypogonadism in men referred for obesity treatment. Neth J Med (2008) 66(3):103-9.

92. Esposito K, Giugliano D. Obesity, the metabolic syndrome, and sexual dysfunction in men. Clin Pharmacol Ther (2011) 90(1):169-73. doi:10.1038/clpt. 2011.91

93. Zhao J, Zhai L, Liu Z, Wu S, Xu L. Leptin level and oxidative stress contribute to obesity-induced low testosterone in murine testicular tissue. Oxid Med Cell Longev. (2014) 2014:190945. doi:10.1155/2014/190945

94. Turner TT, Lysiak JJ. Oxidative stress: a common factor in testicular dysfunction. J Androl (2008) 29(5):488-98. doi:10.2164/jandrol.108.005132

95. De Liz Oliveira Cavalli VL, Cattani D, Heinz Rieg CE, Pierozan P, Zanatta L, Parisotto EB, et al. Roundup disrupts male reproductive functions by triggering calcium-mediated cell death in rat testis and Sertoli cells. Free Radical Biol Med (2013) 65:335-46. doi:10.1016/j.freeradbiomed.2013.06.043

96. Zamoner A, Barreto KP, Filho DW, Sell F, Woehl VM, Rodrigues Guma FC, et al. Propylthiouracil-induced congenital hypothyroidism upregulates vimentin phosphorylation and depletes antioxidant defenses in immature rat testis. $J$ Mol Endocrinol (2008) 40(3-4):125-35. doi:10.1677/JME-07-0089

97. Zamoner A, Barreto KP, Filho DW, Sell F, Woehl VM, Rodrigues Guma FC. Hyperthyroidism in the developing rat testis is associated with oxidative stress and hyperphosphorylated vimentin accumulation. Mol Cell Endocrinol (2007) 267(1-2):116-26. doi:10.1016/i.mce.2007.01.005

98. Stokes VJ, Anderson RA, George JT. How does obesity affect fertility in men and what are the treatment options? Clin Endocrinol (2014). doi:10.1111/cen. 12591

99. Rago V, Aquila S, Guido C, Carpino A. Leptin and its receptor are expressed in the testis and in the epididymis of young and adult pigs. Anat Rec (2009) 292(5):736-45. doi:10.1002/ar.20880

100. Lechan RM, Fekete C. The TRH neuron: a hypothalamic integrator of energy metabolism. Prog Brain Res (2006) 153:209-35. doi:10.1016/S0079-6123(06) 53012-2

101. Kakucska I, Rand W, Lechan RM. Thyrotropin-releasing hormone gene expression in the hypothalamic paraventricular nucleus is dependent upon feedback regulation by both triiodothyronine and thyroxine. Endocrinology (1992) 130(5):2845-50. doi:10.1210/endo.130.5.1572297

102. Segerson TP, Kauer J, Wolfe HC, Mobtaker H, Wu P, Jackson IM, et al. Thyroid hormone regulates TRH biosynthesis in the paraventricular nucleus of the rat hypothalamus. Science (1987) 238(4823):78-80. doi:10.1126/science.3116669

103. Tapia-Arancibia L, Arancibia S, Astier H. Evidence for alpha 1-adrenergic stimulatory control of in vitro release of immunoreactive thyrotropin-releasing hormone from rat median eminence: in vivo corroboration. Endocrinology (1985) 116(6):2314-9. doi:10.1210/endo-116-6-2314

104. Fekete C, Legradi G, Mihaly E, Huang QH, Tatro JB, Rand WM, et al. alpha-Melanocyte-stimulating hormone is contained in nerve terminals innervating thyrotropin-releasing hormone-synthesizing neurons in the hypothalamic paraventricular nucleus and prevents fasting-induced suppression of prothyrotropin-releasing hormone gene expression. J Neurosci (2000) 20(4):1550-8.

105. Fekete C, Mihaly E, Luo LG, Kelly J, Clausen JT, Mao Q, et al. Association of cocaine- and amphetamine-regulated transcript-immunoreactive elements with thyrotropin-releasing hormone-synthesizing neurons in the hypothalamic paraventricular nucleus and its role in the regulation of the hypothalamicpituitary-thyroid axis during fasting. J Neurosci (2000) 20(24):9224-34. 
106. Harris M, Aschkenasi C, Elias CF, Chandrankunnel A, Nillni EA, Bjoorbaek C, et al. Transcriptional regulation of the thyrotropin-releasing hormone gene by leptin and melanocortin signaling. J Clin Invest (2001) 107(1):111-20. doi:10.1172/JCI10741

107. Perello M, Stuart RC, Nillni EA. The role of intracerebroventricular administration of leptin in the stimulation of prothyrotropin releasing hormone neurons in the hypothalamic paraventricular nucleus. Endocrinology (2006) 147(7):3296-306. doi:10.1210/en.2005-1533

108. Toni R, Jackson IM, Lechan RM. Neuropeptide-Y-immunoreactive innervation of thyrotropin-releasing hormone-synthesizing neurons in the rat hypothalamic paraventricular nucleus. Endocrinology (1990) 126(5):2444-53. doi:10.1210/endo-126-5-2444

109. Sawchenko PE, Swanson LW, Grzanna R, Howe PR, Bloom SR, Polak JM. Colocalization of neuropeptide Y immunoreactivity in brainstem catecholaminergic neurons that project to the paraventricular nucleus of the hypothalamus. $J$ Comp Neurol (1985) 241(2):138-53. doi:10.1002/cne.902410203

110. Shioda S, Nakai Y, Sato A, Sunayama S, Shimoda Y. Electron-microscopic cytochemistry of the catecholaminergic innervation of TRH neurons in the rat hypothalamus. Cell Tissue Res (1986) 245(2):247-52. doi:10.1007/BF00213928

111. ter Horst GJ, Luiten PG. The projections of the dorsomedial hypothalamic nucleus in the rat. Brain Res Bull (1986) 16(2):231-48. doi:10.1016/03619230(86)90038-9

112. Zamoner A, Pessoa-Pureur R, Mena Barreto Silva FR. Membrane-initiated actions of thyroid hormones on the male reproductive system. Life Sci (2011) 89(15-16):507-14. doi:10.1016/j.lfs.2011.04.006

113. Zamoner A, Pessoa-Pureur R. Nongenomic actions of thyroid hormones: every why has a wherefore. Immunol. Endocr. Metabol. Agents Med. Chem. (2011) 11:165-78. doi:10.2174/187152211796642765

114. Gereben B, Zavacki AM, Ribich S, Kim BW, Huang SA, Simonides WS, et al. Cellular and molecular basis of deiodinase-regulated thyroid hormone signaling. Endocr Rev (2008) 29(7):898-938. doi:10.1210/er.2008-0019

115. Bates JM, St Germain DL, Galton VA. Expression profiles of the three iodothyronine deiodinases, D1, D2, and D3, in the developing rat. Endocrinology (1999) 140(2):844-51. doi:10.1210/en.140.2.844

116. Wajner SM, dos Santos Wagner M, Melo RC, Parreira GG, Chiarini-Garcia H, Bianco AC, et al. Type 2 iodothyronine deiodinase is highly expressed in germ cells of adult rat testis. J Endocrinol (2007) 194(1):47-54. doi:10.1677/JOE-070106

117. Visser WE, Friesema EC, Jansen J, Visser TJ. Thyroid hormone transport in and out of cells. Trends Endocrinol Metab (2008) 19(2):50-6. doi:10.1016/j. tem.2007.11.003

118. Sande S, Privalsky ML. Identification of TRACs (T3 receptor-associating cofactors), a family of cofactors that associate with, and modulate the activity of, nuclear hormone receptors. Mol Endocrinol (1996) 10(7):813-25. doi:10.1210/mend.10.7.8813722

119. Zamoner A, Pessoa-Pureur R, Silva FR. Membrane-initiated actions of thyroid hormones on the male reproductive system. Life Sci (2011) 89(15-16):507-14. doi:10.1016/j.lfs.2011.04.006

120. Tsai MJ, O'Malley BW. Molecular mechanisms of action of steroid/thyroid receptor superfamily members. Annu Rev Biochem (1994) 63:451-86. doi:10. 1146/annurev.bi.63.070194.002315

121. Yen PM, Ando S, Feng X, Liu Y, Maruvada P, Xia X. Thyroid hormone action at the cellular, genomic and target gene levels. Mol Cell Endocrinol (2006) 246(12):121-7. doi:10.1016/j.mce.2005.11.030

122. Patrick L. Thyroid disruption: mechanism and clinical implications in human health. Altern Med Rev (2009) 14(4):326-46.

123. Baniahmad A, Kohne AC, Renkawitz R. A transferable silencing domain is present in the thyroid hormone receptor, in the v-erbA oncogene product and in the retinoic acid receptor. EMBO J (1992) 11(3):1015-23.

124. Brent GA, Dunn MK, Harney JW, Gulick T, Larsen PR, Moore DD. Thyroid hormone aporeceptor represses T3-inducible promoters and blocks activity of the retinoic acid receptor. New Biol (1989) 1(3):329-36.

125. Damm K, Thompson CC, Evans RM. Protein encoded by v-erbA functions as a thyroid-hormone receptor antagonist. Nature (1989) 339(6226):593-7. doi: $10.1038 / 339593 \mathrm{a} 0$

126. Fondell JD, Brunel F, Hisatake K, Roeder RG. Unliganded thyroid hormone receptor alpha can target TATA-binding protein for transcriptional repression. Mol Cell Biol (1996) 16(1):281-7.
127. Graupner G, Wills KN, Tzukerman M, Zhang XK, Pfahl M. Dual regulatory role for thyroid-hormone receptors allows control of retinoic-acid receptor activity. Nature (1989) 340(6235):653-6. doi:10.1038/340653a0

128. Sap J, Munoz A, Schmitt J, Stunnenberg H, Vennstrom B. Repression of transcription mediated at a thyroid hormone response element by the v-erb-A oncogene product. Nature (1989) 340(6230):242-4. doi:10.1038/340242a0

129. Arambepola NK, Bunick D, Cooke PS. Thyroid hormone effects on androgen receptor messenger RNA expression in rat Sertoli and peritubular cells. $J$ Endocrinol (1998) 156(1):43-50. doi:10.1677/joe.0.1560043

130. Buzzard JJ, Morrison JR, O’Bryan MK, Song Q, Wreford NG. Developmental expression of thyroid hormone receptors in the rat testis. Biol Reprod (2000) 62(3):664-9. doi:10.1095/biolreprod62.3.664

131. Canale D, Agostini M, Giorgilli G, Caglieresi C, Scartabelli G, Nardini V, et al. Thyroid hormone receptors in neonatal, prepubertal, and adult rat testis. $J$ Androl (2001) 22(2):284-8.

132. Rao JN, Liang JY, Chakraborti P, Feng P. Effect of thyroid hormone on the development and gene expression of hormone receptors in rat testes in vivo. $J$ Endocrinol Invest (2003) 26(5):435-43. doi:10.1007/BF03345199

133. Jannini EA, Crescenzi A, Rucci N, Screponi E, Carosa E, de Matteis A, et al. Ontogenetic pattern of thyroid hormone receptor expression in the human testis. J Clin Endocrinol Metab (2000) 85(9):3453-7. doi:10.1210/jcem.85.9. 6803

134. Nakai A, Sakurai A, Bell GI, DeGroot LJ. Characterization of a third human thyroid hormone receptor coexpressed with other thyroid hormone receptors in several tissues. Mol Endocrinol (1988) 2(11):1087-92. doi:10.1210/mend-211-1087

135. Zanatta AP, Zanatta L, Gonçalves R, Zamoner A, Silva FR. Rapid responses to reverse $\mathrm{T}_{3}$ hormone in immature rat Sertoli cells: calcium uptake and exocytosis mediated by integrin. PLoS One (2013) 8(10):e77176. doi:10.1371/journal. pone. 0077176

136. Zanatta AP, Zanatta L, Goncalves R, Zamoner A, Mena Barreto Silva FR. Integrin participates in the effect of thyroxine on plasma membrane in immature rat testis. Biochim Biophys Acta (2013) 1830(3):2629-37. doi:10.1016/j.bbagen. 2012.10.022

137. Menegaz D, Royer C, Rosso A, Pacheco de Souza AZ, Soares dos Santos AR, Mena Barreto Silva FR. Rapid stimulatory effect of thyroxine on plasma membrane transport systems: calcium uptake and neutral amino acid accumulation in immature rat testis. Int J Biochem Cell Biol (2010) 42(6):1046-51. doi:10.1016/j.biocel.2010.03.015

138. Menegaz D, Zamoner A, Royer C, Leite L, Bortolottoc Z, Silva F. Rapid responses to thyroxine in the testis: active protein synthesis-independent pathway. $\mathrm{Mol}$ Cell Endocrinol (2006) 246(1-2):128-34. doi:10.1016/j.mce.2005.11.019

139. Mendis-Handagama SM, Siril Ariyaratne HB. Leydig cells, thyroid hormones and steroidogenesis. Indian J Exp Biol (2005) 43(11):939-62.

140. Fumel B, Guerquin MJ, Livera G, Staub C, Magistrini M, Gauthier C, et al. Thyroid hormone limits postnatal Sertoli cell proliferation in vivo by activation of its alphal isoform receptor (TRalphal) present in these cells and by regulation of Cdk4/JunD/c-myc mRNA levels in mice. Biol Reprod (2012) 87(1):16,1-9. doi:10.1095/biolreprod.111.098418

141. Orth JM, Gunsalus GL, Lamperti AA. Evidence from Sertoli cell-depleted rats indicates that spermatid number in adults depends on numbers of Sertoli cells produced during perinatal development. Endocrinology (1988) 122(3):787-94. doi:10.1210/endo-122-3-787

142. Tarulli GA, Stanton PG, Meachem SJ. Is the adult Sertoli cell terminally differentiated? Biol Reprod (2012) 87(1):1-11. doi:10.1095/biolreprod.111.095091

143. Holsberger DR, Buchold GM, Leal MC, Kiesewetter SE, O’Brien DA, Hess RA, et al. Cell-cycle inhibitors p27Kip1 and p21Cip1 regulate murine Sertoli cell proliferation. Biol Reprod (2005) 72(6):1429-36. doi:10.1095/biolreprod.105. 040386

144. Ulisse S, Jannini EA, Carosa E, Piersanti D, Graziano FM, D’Armiento M. Inhibition of aromatase activity in rat Sertoli cells by thyroid hormone. J Endocrinol (1994) 140(3):431-6. doi:10.1677/joe.0.1400431

145. Ando S, Sirianni R, Forastieri P, Casaburi I, Lanzino M, Rago V, et al. Aromatase expression in prepuberal Sertoli cells: effect of thyroid hormone. Mol Cell Endocrinol (2001) 178(1-2):11-21. doi:10.1016/S0303-7207(01) 00443-9

146. Catalano S, Pezzi V, Chimento A, Giordano C, Carpino A, Young M, et al. Triiodothyronine decreases the activity of the proximal promoter (PII) of the 
aromatase gene in the mouse Sertoli cell line, TM4. Mol Endocrinol (2003) 17(5):923-34. doi:10.1210/me.2002-0102

147. Maran RR. Thyroid hormones: their role in testicular steroidogenesis. Arch Androl (2003) 49(5):375-88. doi:10.1080/01485010390204968

148. Maran RR, Arunakaran J, Aruldhas MM. T3 directly stimulates basal and modulates LH induced testosterone and oestradiol production by rat Leydig cells in vitro. Endocr J (2000) 47(4):417-28. doi:10.1507/endocri.47.417

149. Romano RM, Bargi-Souza P, Brunetto EL, Goulart-Silva F, Avellar MC, Oliveira CA, et al. Hypothyroidism in adult male rats alters posttranscriptional mechanisms of luteinizing hormone biosynthesis. Thyroid (2013) 23(4):497-505. doi:10.1089/thy.2011.0514

150. Gilleron J, Nebout M, Scarabelli L, Senegas-Balas F, Palmero S, Segretain D, et al. A potential novel mechanism involving connexin 43 gap junction for control of sertoli cell proliferation by thyroid hormones. J Cell Physiol (2006) 209(1):153-61. doi:10.1002/jcp.20716

151. Levine N, Marsh DJ. Micropuncture studies of the electrochemical aspects of fluid and electrolyte transport in individual seminiferous tubules, the epididymis and the vas deferens in rats. J Physiol (1971) 213(3):557-70.

152. Jégou B. The Sertoli cell in vivo and in vitro. Cell Biol Toxicol (1992) 8(3):49-54. doi:10.1007/BF00130510

153. Ko WH, Chan HC, Chew SB, Wong PY. Regulated anion secretion in cultured epithelia from Sertoli cells of immature rats. J Physiol (1998) 512(Pt 2):471-80. doi:10.1111/j.1469-7793.1998.471be.x

154. Ko WH, Au CL, Yip CY. Multiple purinergic receptors lead to intracellular calcium increases in cultured rat Sertoli cells. Life Sci (2003) 72(13):1519-35. doi:10.1016/S0024-3205(02)02410-4

155. Zanatta AP, Zanatta L, Goncalves R, Zamoner A, Mena Barreto Silva FR. Rapid responses to reverse T-3 hormone in immature rat sertoli cells: calcium uptake and exocytosis mediated by integrin. PLoS One (2013) 8(10):1-11. doi:10.1371/journal.pone.0077176

156. Tindall DJ, Vitale R, Means AR. Androgen binding protein as a biochemical marker of formation of the blood-testis barrier. Endocrinology (1975) 97(3):636-48. doi:10.1210/endo-97-3-636

157. Carreau S, Silandre D, Bois C, Bouraima H, Galeraud-Denis I, Delalande C. Estrogens: a new player in spermatogenesis. Folia Histochem Cytobiol (2007) 45(Suppl 1):S5-10.

158. Papadopoulos V, Carreau S, Szerman-Joly E, Drosdowsky MA, Dehennin L, Scholler R. Rat testis 17 beta-estradiol: identification by gas chromatographymass spectrometry and age related cellular distribution. J Steroid Biochem (1986) 24(6):1211-6. doi:10.1016/0022-4731(86)90385-7

159. Sisci D, Panno ML, Salerno M, Maggiolini M, Pezzi V, Morrone EG, et al. A time course study on the "in vitro" effects of T3 and testosterone on androgen and estrogen receptors in peripuberal primary rat Sertoli cells. Exp Clin Endocrinol Diabetes (1997) 105(4):218-24. doi:10.1055/s-0029-1211755

160. Pezzi V, Panno ML, Sirianni R, Forastieri P, Casaburi I, Lanzino M, et al. Effects of tri-iodothyronine on alternative splicing events in the coding region of cytochrome P450 aromatase in immature rat Sertoli cells. J Endocrinol (2001) 170(2):381-93. doi:10.1677/joe.0.1700381

161. Chiao YC, Lee HY, Wang SW, Hwang JJ, Chien CH, Huang SW, et al. Regulation of thyroid hormones on the production of testosterone in rats. $J$ Cell Biochem (1999) 73(4):554-62. doi:10.1002/(SICI)1097-4644(19990615) 73:4<554::AID-JCB13>3.3.CO;2-C

162. Manna PR, Kero J, Tena-Sempere M, Pakarinen P, Stocco DM, Huhtaniemi IT. Assessment of mechanisms of thyroid hormone action in mouse Leydig cells: regulation of the steroidogenic acute regulatory protein, steroidogenesis, and luteinizing hormone receptor function. Endocrinology (2001) 142(1):319-31. doi:10.1210/endo.142.1.7900

163. Manna PR, Roy P, Clark BJ, Stocco DM, Huhtaniemi IT. Interaction of thyroid hormone and steroidogenic acute regulatory (StAR) protein in the regulation of murine Leydig cell steroidogenesis. J Steroid Biochem Mol Biol (2001) 76(15):167-77. doi:10.1016/S0960-0760(00)00156-4

164. Krassas GE, Poppe K, Glinoer D. Thyroid function and human reproductive health. Endocr Rev (2010) 31(5):702-55. doi:10.1210/er.2009-0041

165. Iglesias P, Diez JJ. Thyroid dysfunction and kidney disease. Eur J Endocrinol (2009) 160(4):503-15. doi:10.1530/EJE-08-0837

166. Ascoli M, Fanelli F, Segaloff DL. The lutropin/choriogonadotropin receptor, a 2002 perspective. Endocr Rev (2002) 23(2):141-74. doi:10.1210/edrv.23.2.0462
167. Ahima RS, Flier JS. Leptin. Annu Rev Physiol (2000) 62:413-37. doi:10.1146/ annurev.physiol.62.1.413

168. Araujo RL, Andrade BM, da Silva ML, Ferreira AC, Carvalho DP. Tissuespecific deiodinase regulation during food restriction and low replacement dose of leptin in rats. Am J Physiol Endocrinol Metab (2009) 296(5):E1157-63. doi:10.1152/ajpendo.90869.2008

169. Cabanelas A, Lisboa PC, Moura EG, Pazos-Moura CC. Leptin acute modulation of the $5^{\prime}$-deiodinase activities in hypothalamus, pituitary and brown adipose tissue of fed rats. Horm Metab Res (2006) 38(8):481-5. doi:10.1055/s2006-949527

170. Ortiga-Carvalho TM, Oliveira KJ, Soares BA, Pazos-Moura CC. The role of leptin in the regulation of TSH secretion in the fed state: in vivo and in vitro studies. J Endocrinol (2002) 174(1):121-5. doi:10.1677/joe.0.1740121

171. Seoane LM, Carro E, Tovar S, Casanueva FF, Dieguez C. Regulation of in vivo TSH secretion by leptin. Regul Pept (2000) 92(1-3):25-9. doi:10.1016/S01670115(00)00145-2

172. Elias CF, Kelly JF, Lee CE, Ahima RS, Drucker DJ, Saper CB, et al. Chemical characterization of leptin-activated neurons in the rat brain. J Comp Neurol (2000) 423(2):261-81. doi:10.1002/1096-9861(20000724)423:2<261::AID-CNE6>3. $0 . \mathrm{CO} ; 2-6$

173. Guo F, Bakal K, Minokoshi Y, Hollenberg AN. Leptin signaling targets the thyrotropin-releasing hormone gene promoter in vivo. Endocrinology (2004) 145(5):2221-7. doi:10.1210/en.2003-1312

174. Nillni EA, Vaslet C, Harris M, Hollenberg A, Bjorbak C, Flier JS. Leptin regulates prothyrotropin-releasing hormone biosynthesis. Evidence for direct and indirect pathways. J Biol Chem (2000) 275(46):36124-33. doi:10.1074/jbc. M003549200

175. Kim MS, Small CJ, Stanley SA, Morgan DG, Seal LJ, Kong WM, et al. The central melanocortin system affects the hypothalamo-pituitary thyroid axis and may mediate the effect of leptin. J Clin Invest (2000) 105(7):1005-11. doi:10.1172/JCI8857

176. Legradi G, Emerson CH, Ahima RS, Flier JS, Lechan RM. Leptin prevents fasting-induced suppression of prothyrotropin-releasing hormone messenger ribonucleic acid in neurons of the hypothalamic paraventricular nucleus. Endocrinology (1997) 138(6):2569-76. doi:10.1210/endo.138.6.5209

177. Costa-e-Sousa RH, Hollenberg AN. Minireview: the neural regulation of the hypothalamic-pituitary-thyroid axis. Endocrinology (2012) 153(9):4128-35. doi:10.1210/en.2012-1467

178. Nillni EA. Regulation of the hypothalamic thyrotropin releasing hormone $(\mathrm{TRH})$ neuron by neuronal and peripheral inputs. Front Neuroendocrinol (2010) 31(2):134-56. doi:10.1016/j.yfrne.2010.01.001

179. Menendez C, Baldelli R, Camina JP, Escudero B, Peino R, Dieguez C, et al. TSH stimulates leptin secretion by a direct effect on adipocytes. J Endocrinol (2003) 176(1):7-12. doi:10.1677/joe.0.1760007

180. Casanueva FF, Dieguez C. Neuroendocrine regulation and actions of leptin. Front Neuroendocrinol (1999) 20(4):317-63. doi:10.1006/frne.1999. 0187

181. Coiro V, Volpi R, Chiodera P. Mediation by nitric oxide of TRH-, but not metoclopramide-stimulated TSH secretion in humans. Neuroreport (1995) 6(8):1174-6. doi:10.1097/00001756-199505300-00025

182. Radwanska P, Kosior-Korzecka U. Effect of leptin on thyroid-stimulating hormone secretion and nitric oxide release from pituitary cells of ewe lambs in vitro. J Physiol Pharmacol (2014) 65(1):145-51.

183. Mantzoros CS, Flier JS, Rogol AD. A longitudinal assessment of hormonal and physical alterations during normal puberty in boys. V. Rising leptin levels may signal the onset of puberty. J Clin Endocrinol Metabol. (1997) 82(4):1066-70. doi:10.1210/jcem.82.4.3878

184. Carlsson B, Ankarberg C, Rosberg S, Norjavaara E, Albertsson-Wikland K, Carlsson LM. Serum leptin concentrations in relation to pubertal development. Archi Dis Child. (1997) 77(5):396-400. doi:10.1136/adc.77.5.396

185. Mann DR, Akinbami MA, Gould KG, Castracane VD. Leptin and thyroxine during sexual development in male monkeys: effect of neonatal gonadotropinreleasing hormone antagonist treatment and delayed puberty on the developmental pattern of leptin and thyroxine secretion. Eur J Endocrinol (2002) 146(6):891-8. doi:10.1530/eje.0.1460891

186. Farooqi IS, Matarese G, Lord GM, Keogh JM, Lawrence E, Agwu C, et al. Beneficial effects of leptin on obesity, $\mathrm{T}$ cell hyporesponsiveness, and 
neuroendocrine/metabolic dysfunction of human congenital leptin deficiency. J Clin Invest (2002) 110(8):1093-103. doi:10.1172/JCI0215693

187. Gill MS, Hall CM, Tillmann V, Clayton PE. Constitutional delay in growth and puberty (CDGP) is associated with hypoleptinaemia. Clin Endocrinol (Oxf). (1999) 50(6):721-6. doi:10.1046/j.1365-2265.1999.00736.x

188. Sera N, Yokoyama N, Abe Y, Ide A, Imaizumi M, Usa T, et al. Thyroid hormones influence serum leptin levels in patients with Graves' disease during suppression of beta-adrenergic receptors. Thyroid (2000) 10(8):641-6. doi:10.1089/10507250050137707

189. Asami T, Ciomarten T, Uchiyama M. Relationship between serum leptin and thyroid hormones in children. Pediatr Int (2000) 42(3):293-5. doi:10.1046/j. 1442-200x.2000.01220.x

190. Li R, Hu Y, Ni Y, Xia D, Grossmann R, Zhao R. Leptin stimulates hepatic activation of thyroid hormones and promotes early posthatch growth in the chicken. Comp Biochem Physiol A Mol Integr Physiol (2011) 160(2):200-6. doi:10.1016/j.cbpa.2011.06.001

191. Ortega FJ, Jilkova ZM, Moreno-Navarrete JM, Pavelka S, Rodriguez-Hermosa JI, Kopeck Ygrave J, et al. Type I iodothyronine $5^{\prime}$-deiodinase mRNA and activity is increased in adipose tissue of obese subjects. Int J Obes (2012) 36(2):320-4. doi:10.1038/ijo.2011.101

192. Calvino C, Souza LL, Costa-e-Sousa RH, Almeida NA, Trevenzoli IH, PazosMoura CC. Hypothyroidism reduces ObRb-STAT3 leptin signalling in the hypothalamus and pituitary of rats associated with resistance to leptin acute anorectic action. J Endocrinol (2012) 215(1):129-35. doi:10.1530/JOE-11-0476

193. Groba C, Mayerl S, van Mullem AA, Visser TJ, Darras VM, Habenicht AJ, et al. Hypothyroidism compromises hypothalamic leptin signaling in mice. Mol Endocrinol (2013) 27(4):586-597. doi:10.1210/me.2012-1311

Conflict of Interest Statement: The authors declare that the research was conducted in the absence of any commercial or financial relationships that could be construed as a potential conflict of interest.

Received: 03 July 2014; accepted: 10 November 2014; published online: 25 November 2014.

Citation: Ramos CF and Zamoner A (2014) Thyroid hormone and leptin in the testis. Front. Endocrinol. 5:198. doi: 10.3389/fendo.2014.00198

This article was submitted to Experimental Endocrinology, a section of the journal Frontiers in Endocrinology.

Copyright $\odot 2014$ Ramos and Zamoner. This is an open-access article distributed under the terms of the Creative Commons Attribution License (CC BY). The use, distribution or reproduction in other forums is permitted, provided the original author(s) or licensor are credited and that the original publication in this journal is cited, in accordance with accepted academic practice. No use, distribution or reproduction is permitted which does not comply with these terms. 